\title{
Redesign of the Curriculum for Improvement of Graduates and Lecture Career of the Animal Science Study Program
}

\author{
Khalil $^{1}$, Adrizal ${ }^{1}$ \\ ${ }^{1}$ Department of Animal Nutrition and Feed Technology, Andalas University, Campus II Payakumbuh, West \\ Sumatra, Indonesia \\ *Corresponding author. Email: khalil@ansci.unand.ac.id
}

\begin{abstract}
The challenges facing the animal science study program of Campus II Payakumbuh in implementing the learning process were poor knowledge and skills of students and graduates. The academic grades did not reflect the actual skills needed to work in the livestock areas. This research redesigned the curriculum to strengthen competence by referring to the job opportunities and career of lecturers. The research was initiated by evaluating the outcomes of the current applied curriculum by observing the understanding, skills, and attitudes of students by implementing a research project. Results found that the students' working performances were below expected, presumably due to poor course understanding, practical experiences, and working attitude. The curriculum was redesigned to achieve basic and specific expertise competencies. Basic competence is the minimum competency that must be possessed by an animal science student, while the particular expertise competency is an additional competency related to intended specialization. Course subjects were translated based on the intended competence achieved, and learning outcomes were evaluated based on intended competency. Basic sciences and appropriate learning processes strengthened the curriculum for skills, character building, and professional attitude. Lecturers tailored their expertise and intellectual capacity in teaching, education, research, and community services.
\end{abstract}

Keywords: Curriculum, competencies, learning outcomes

\section{INTRODUCTION}

The study program of Animal Science (SPAS), Andalas University Campus II Payakumbuh, started academic activities in the odd semester 2012/2013 academic year. The SPAS was established at the request of the local government of Payakumbuh, which includes Payakumbuh city and Limapuluhkota district. Payakumbuh is a national center of animal production, supported by the presence of several national-level institutions related to livestock, such as the Center for Breeding Cattle and Forage (BPTU-HPT) Padang Mengatas, Veterinary Research Center (BAVET), Baso, and the state Agricultural Polytechnic (Tanjung Pati). Livestock farming has encouraged various local businesses related to livestock, such as poultry shops, livestock product processing business, and culinary services. SPAS' existence supports Payakumbuh as the center of the national, regional, and international livestock industry. The SPAS served the people interested in livestock business through education, research, and public services.

Education programs intend to serve the community (in this case, students) who wish to gain expertise, knowledge, and skills in various aspects related to animal husbandry and business. The education program carries out through a learning process based on the curriculum. The curriculum is a specific study program and defined as a set of plans and arrangements of course subjects, methods, and assessment of learning outcomes [1]. The curriculum evaluated and revised to accommodate the development of animal science and technology, society's needs, education paradigm, and appropriate policy developments in technology and industry.

There are four factors considered in designing a better curriculum for competent students and graduates in livestock farming and business: the academic capacity of enrolled students, intended specific expertise, policycampus freedom policy, and the industrial revolution 4.0. Most students enrolled in the SPAS have a low passing grade, derived from non-exact majors and non-favorite schools. Their academic ability to understand and master the course material is limited. There are also problems with social attitude. Grades are allegedly not by the actual intellectual abilities and skills of students. It is easily observed during the students preparing proposals and implementing research, writing, presentation, and discussion of the results in the scientific papers and seminars and final undergraduate exams. It impacts 
graduates' quality and competitiveness in obtaining jobs and ultimately reduces the community's interest in enrolling in the study program. On the other hand, the teaching process considers the fulfillment of performance load requirements rather than lecturers' expertise or competence. It also hurts the expertise performance of the lecturer in postgraduate studies, research, and community service.

Basic course subjects should be strengthened to improve and equalize their basic science related to animal science. The number of course subjects should be reduced and presented in an integrated system (blended course). The course material does not overlap, mutual support, and makes it easy for the student to reconstruct into an intact knowledge and skills. The campus freedom policy allows students to take courses outside the study program and faculty. the SPAS student might take the basic science courses at the more relevant faculty or department in the Andalas University. The curriculum should design to accommodate the future development of technology and industry. The course materials should encourage the students to master a foreign language, artificial intelligence program, digital devices, and the internet related to livestock production, management, and business.

The present research aimed to evaluate the outcome of the current applied curriculum on students' working performances and redesign the curriculum to achieve basic and expert competence and ensure the faculty's career development (lecturer).

\section{METHODOLOGY}

\subsection{Evaluation of Current Curriculum}

The study was initiated by evaluating the impact of the current curriculum and learning outcomes (life skills) [2] on the SPAS students' competencies enrolled at Campus II Payakumbuh. Competence might be defined as a series of intelligent action, full responsibility of a person to be considered capable by the public in carrying out tasks in their expertise [3]. Four students enrolled in the $7^{\text {th }}$ semester had prepared a research proposal titled "Studies on the use of the local material-based mineral formula to improve production and reproduction performances of Muscovy ducks raising under a semi-intensive breeding system.". They were closely observed for four months (from late January to mid-May 2020) in implementing the research proposals, ranging from the research preparation (cages, feed, and livestock), daily duck management, data recording and analyzing, and thesis writing. The working performances were evaluated based on the following three aspects, namely: text understanding, working skills (skills), and working attitude (soft skills). The variables measured for each element showed in Table 1. The students were regularly asked and invited to discuss to elaborate information on their experiences during the last six semesters of the lecture, laboratory works, assignments and exams in the Campus II Payakumbuh related to the three aspects of curriculum outcomes of the above parameter observed.

\subsection{Competency-Based Curriculum Design}

In the second stage, the curriculum was reconstructed to strengthen basic science and to achieve two of the intended competencies mastered by students and graduates:

a. Basic competence or minimum competency as a Bachelor of Animal Science, and

b. Expertise competencies based on the selected specialization chosen after the 4th semester.

The SPAS of campus II Payakumbuh directed the students to select one of the four expertise areas, called specialization, started in the 5th semester, i.e.:

a. Animal Nutrition and Feed Technology (INTP)

b. Animal Production Technology (TPT)

c. Livestock Business and Development (PBP)

d. Livestock Product Processing Technology (THT). Competencies are described based on the roles or types of jobs or positions that are relevant to each expertise. This role is then translated into course subjects required by students. Each course had a clear contribution to an intact competency. The curriculum also comes with a description of the learning process and evaluation of the achievements of the learning outcomes, attitude and character-building (soft skills), and load settings and tasks of lecturers. The developed curriculum was subsequently presented to students and faculty members to get feedback and suggestions before finalization.

\section{RESULTS AND DISCUSSION}

\subsection{Evaluation of Current Applied Curriculum}

The current curriculum applied in the SPAS at Campus II Payakumbuh started in the 2014 academic year [4]. There are in total 84-course subjects. They were categorized into compulsory subjects (116 credits) and electives ( $\geq 28$ credits). It was completed with the vision, mission, goals, and objectives of the study program and graduates' profile and competence. The curriculum listed the vision, mission, goals, and objectives of the study program and the face and competence of graduates. However, course subjects were not designed to refer to the expected competencies. Course subjects were not elaborated based on standard competencies and were impressed to justify the four departments' equal distribution. Coverage of course material was also very limited minimal, which is characterized by a low credit (2-3 SKS). 
Table 1. Aspects and variables observed in the study of student competence in conducting a research project

\begin{tabular}{|c|c|c|c|c|}
\hline No & Aspect & & Variable observed & Remark \\
\hline 1 & Understanding & $\begin{array}{l}\mathrm{c} \\
\mathrm{d}\end{array}$ & $\begin{array}{l}\text { Distribution and allocation of duck into research units } \\
\text { based on measured body weight and experimental design } \\
\text { Preparation of experimental diets based on the formula } \\
\text { Setup data form by the parameters measured } \\
\text { Writing and description of the research methodology based } \\
\text { on undertaken activities. }\end{array}$ & $\begin{array}{l}\text { The formulas are listed in the } \\
\text { proposal. } \\
\text { Individual parameter } \\
\text { Writing Chapter } 3 \text { while being } \\
\text { fresh in the field }\end{array}$ \\
\hline 2 & Skills & d & $\begin{array}{l}\text { Measurement of duck body weight (initial and end } \\
\text { bodyweight) } \\
\text { Measurement and recording of data by the setup } \\
\text { parameters } \\
\text { Feeding and preparing of drinking water based on duck } \\
\text { requirement } \\
\text { The calculation, analysis, and presentation of research data } \\
\text { according to the research design and purposes }\end{array}$ & $\begin{array}{l}\text { Individual parameter } \\
\text { Described in the research proposal } \\
\text { Using the excel spreadsheets }\end{array}$ \\
\hline 3 & Attitude & a & $\begin{array}{l}\text { Fulfillment of the setup targets regarding the data handling } \\
\text { and analyzing } \\
\text { Performances in implementation of daily tasks in the duck } \\
\text { raising } \\
\text { Fulfillment of obligations (appointments, tasks, funding) } \\
\text { The dynamic interaction with a fellow student (team } \\
\text { members). }\end{array}$ & $\begin{array}{l}\text { Discipline, obedience, seriousness } \\
\text { Honesty, responsibility, } \\
\text { independence } \\
\text { Honesty, obedience, responsibility } \\
\text { Cooperation, responsibility }\end{array}$ \\
\hline
\end{tabular}

Students' working performance in conducting research projects as the learning outcomes is summarized in Table 2 . The results showed the students had fast no experience in most of the research activities. The students also had difficulty to understand and carry out the activities listed in their prepared research proposal. It is presumably partly described in the proposal were not their ideas (plagiarism). The poor understanding and skills were also not supported by sufficient working attitude or ethic, especially honesty, discipline, obedience, and sincerity. The students simply obeyed and actually carried out the task properly when they were commanded and controlled directly. They had insufficient self-reliance and responsibility.

\subsection{Strengthening Basic Sciences}

Animal Science and livestock business are closely related to Chemistry, Biology, Mathematics, Physics, Economics, and Sociology [5] (Table 3). The students' success in understanding and explore animal science and livestock business depends on the ability to master all these basic sciences. Teaching methods for the basic courses must be offered with the most effective strategy for gaining their understanding and interest. As previously mentioned, most of the SPAS students had relatively low ability in these basic sciences. Therefore, these subject's teaching should submit to the faculties that have competent and experienced lecturer. These basic science subjects need to be equipped with a manual and sufficient practical works.
The basic courses should be completed during the first and second semesters. In line with the freedom-campus policy, the teaching of the basic course subjects should be submitted to the relevant Faculties at the Andalas University, such as the Faculty of Mathematics and Natural Sciences (MIPA), Faculty of Economics, and the Faculty of Social and Political Sciences (Social) where the lecturers' related fields and facilities adequate laboratory are available.

\subsection{Basic Competencies}

Education of animal science and livestock business aims to create students and graduates able to increase animals' added value as biological resources into economic and social resources. Graduates might work both in animal husbandry and other fields related to livestock and animal husbandry. Students and graduates of animal science required a basic knowledge and skill that means a necessary knowledge and skill (necessary skill) to become a livestock farmer or businessmen. At the end of year two or after attending the course for four semesters, students are expected to become entrepreneurs in livestock farming (farmers) or manage the farm in economic scale (business). These necessary skills should be offered during the first of four semesters. The mastered already a minimum knowledge and skill in the livestock farming at the end of the 2nd year study. Competences for these necessary skills were outlined in the various roles listed in Table 5 and 6. 
Table 2. The results of observing student competencies in carrying out research projects that are associated with curriculum outcomes

\begin{tabular}{|c|c|c|c|c|c|c|}
\hline No & Aspect & & Variable observed & Findings & Causing factors: & Remarks \\
\hline \multirow{4}{*}{1} & \multirow{4}{*}{ Understanding } & $\mathrm{a}$ & $\begin{array}{l}\text { Distribution and allocation of duck into } \\
\text { research units based on body weight and } \\
\text { experimental design }\end{array}$ & $\begin{array}{l}\text { Students are not able to explain the procedure } \\
\text { before weighing and share of ducks. }\end{array}$ & $\begin{array}{l}\text { Students claimed to have no experience } \\
\text { during their previous studies. }\end{array}$ & $\begin{array}{l}\text { Described in the } \\
\text { research proposal }\end{array}$ \\
\hline & & $\mathrm{b}$ & $\begin{array}{l}\text { Preparation of experimental diets based } \\
\text { on the formulas }\end{array}$ & $\begin{array}{l}\text { Three students could not calculate the amount } \\
\text { of each feed ingredient to weight according to } \\
\text { the formula. }\end{array}$ & $\begin{array}{l}\text { Students who do not understand } \\
\text { formulating formula will also not be able } \\
\text { to prepare feed according to recipes. }\end{array}$ & $\begin{array}{l}\text { The formula has been } \\
\text { prepared and listed in } \\
\text { the proposal. }\end{array}$ \\
\hline & & $\mathrm{c}$ & $\begin{array}{l}\text { Setup data form according to the } \\
\text { parameters measured }\end{array}$ & $\begin{array}{l}\text { Data was only recorded manually on a book } \\
\text { note or a paper sheet, without structured or } \\
\text { arranged according to treatments and } \\
\text { replications }\end{array}$ & $\begin{array}{l}\text { Students did not fully understand the } \\
\text { importance of systematically recording } \\
\text { data for the evaluation and facilitate the } \\
\text { calculation. }\end{array}$ & $\begin{array}{l}\text { Individual parameters } \\
\text { are described in the } \\
\text { proposal. }\end{array}$ \\
\hline & & d & $\begin{array}{l}\text { Writing and description of the research } \\
\text { methodology following the activities that } \\
\text { have been undertaken. }\end{array}$ & $\begin{array}{l}\text { No student was capable of addressing the } \\
\text { writing paper until the research ended. }\end{array}$ & $\begin{array}{l}\text { Students poorly trained to write scientific } \\
\text { papers, even tough to describe activities } \\
\text { have done by themselves }\end{array}$ & $\begin{array}{l}\text { Writing Chapter } 3 \\
\text { (materials } \\
\text { methods) while still } \\
\text { fresh in mind }\end{array}$ \\
\hline \multirow{4}{*}{2} & \multirow{4}{*}{ Skills } & $\mathrm{a}$ & $\begin{array}{l}\text { Measurement of duck body weight } \\
\text { (initial and end bodyweight) }\end{array}$ & $\begin{array}{l}\text { Ducks were stress by handling and weighing, } \\
\text { and it took a long time }\end{array}$ & $\begin{array}{l}\text { Students looked awkward and could not } \\
\text { handle animals properly }\end{array}$ & $\begin{array}{l}\text { It was the first } \\
\text { experience }\end{array}$ \\
\hline & & $\mathrm{b}$ & $\begin{array}{l}\text { Measurement and recording of data } \\
\text { following the setup parameters }\end{array}$ & $\begin{array}{l}\text { Frequent errors and took a long time to measure } \\
\text { and gain data. }\end{array}$ & & $\begin{array}{l}\text { Procedures stated in } \\
\text { the proposal. }\end{array}$ \\
\hline & & $\mathrm{c}$ & $\begin{array}{l}\text { Feeding and preparing of drinking water } \\
\text { based on duck requirement }\end{array}$ & $\begin{array}{l}\text { Feed and water spilled out, drinking water } \\
\text { spoiled (manure, feed). }\end{array}$ & $\begin{array}{l}\text { Students were not able to estimate the } \\
\text { needs of livestock, and livestock feeding } \\
\text { habit was less understood. }\end{array}$ & \\
\hline & & d & $\begin{array}{l}\text { The calculation, analysis, and } \\
\text { presentation of research data following } \\
\text { the research design and purpose. }\end{array}$ & $\begin{array}{l}\text { A lot of mistakes in the preparation and } \\
\text { calculation of data, as well as take a long time }\end{array}$ & $\begin{array}{l}\text { Students had difficulty in handling large } \\
\text { amounts of data and have not been } \\
\text { accustomed to using the excel program. }\end{array}$ & $\begin{array}{l}\text { Using the Excel } \\
\text { program and data } \\
\text { form in a worksheet } \\
\text { has prepared }\end{array}$ \\
\hline \multirow{4}{*}{3} & \multirow{4}{*}{ Attitude } & $\mathrm{a}$ & $\begin{array}{l}\text { The fulfillment time the targeted } \\
\text { regarding the data handling and } \\
\text { analyzing }\end{array}$ & $\begin{array}{l}\text { No student was able to meet the setup target of } \\
\text { time }\end{array}$ & $\begin{array}{l}\text { Students wasted a lot of time and not work } \\
\text { in earnest }\end{array}$ & $\begin{array}{l}\text { Discipline, } \\
\text { obedience, sincerity }\end{array}$ \\
\hline & & $\mathrm{b}$ & $\begin{array}{l}\text { Implementation of tasks in the daily duck } \\
\text { raising and management }\end{array}$ & $\begin{array}{l}\text { Students tended to choose comfortable and light } \\
\text { jobs, playing with gadgets while working. }\end{array}$ & $\begin{array}{l}\text { Students were only serious work if } \\
\text { monitored or supervised directly (by the } \\
\text { lecturer) }\end{array}$ & $\begin{array}{l}\text { Honesty, } \\
\text { responsibility, } \\
\text { independence }\end{array}$ \\
\hline & & $\mathrm{c}$ & $\begin{array}{l}\text { Fulfillment of obligations (appointments, } \\
\text { tasks, funding) }\end{array}$ & $\begin{array}{l}\text { Funds are not met according to the agreement, } \\
\text { and there are automated expenses. }\end{array}$ & $\begin{array}{l}\text { Non-compliance in fulfilling promises and } \\
\text { agreements that have made together }\end{array}$ & $\begin{array}{l}\text { Honesty, compliance, } \\
\text { responsibility }\end{array}$ \\
\hline & & d & $\begin{array}{l}\text { The dynamics of interaction with other } \\
\text { fellow students (team members). }\end{array}$ & $\begin{array}{l}\text { Complaints and objections behaviors that } \\
\text { interfere with the performance of the team } \\
\text { members }\end{array}$ & $\begin{array}{l}\text { Students carried out tasks not according to } \\
\text { time, load, and procedures prescribed. }\end{array}$ & $\begin{array}{l}\text { Cooperation, } \\
\text { responsibility }\end{array}$ \\
\hline
\end{tabular}


Table 3. Basic science courses required by the SPAS

\begin{tabular}{cllc}
\hline No & \multicolumn{1}{c}{ Group } & \multicolumn{1}{c}{ Subject } & \multicolumn{1}{c}{ SKS } \\
\hline 1 & Chemistry & Inorganic Chemistry, Organic Chemistry & $3(2-1)$ \\
2 & Mathematics & Basic Mathematics, Calculus & $3(2-1)$ \\
3 & Biology & Nutrition Physiology, Reproductive Physiology, & $3(2-1)$ \\
& & Anatomy, Genetics & $3(2-1)$ \\
4 & Physic & Climatology & $3(2-1)$ \\
5 & Economy & Microeconomics, Macroeconomics & $3(2-1)$ \\
6 & Sociology & Social change & \\
\hline
\end{tabular}

\subsection{Expertise Competency}

Besides having basic competence, graduates are expected to have an additional special competence related to their minor to strengthen competitiveness in various companies, agencies, or other institutions related to livestock farming and busines. At the end of the fourth semester, students must choose one of the four departments as areas of expertise, which is called specialization. According to Gillespie and Flanders [6], many companies have various work roles undertaken by undergraduate animal husbandry (Table 6). In general, the characteristics of each department can be characterized as follows:
- Animal Nutrition and Feed Technologyeducate students to be able in utilization and enhancing the value of natural resource use as animal feed

- Animal Production Technology department educates students to increase productivity and product quality by improving the genetic potential of livestock, reproduction, and rearing systems.

- The Livestock Business and Development educates students to utilize livestock and all aspects related to animal husbandry as economic and social resources.

- Livestock Product Processing Technology emphasizes efforts to increase livestock products' added value to increase livestock business income.

Table 4. Description of basic competencies

\begin{tabular}{l}
$\begin{array}{l}\text { Type of work } \\
\text { Role }\end{array}$ \\
$\begin{array}{l}\text { Livestock farming and business } \\
\text { Manage commercial-scale farms raising one or several types of livestock in an integrated } \\
\text { farming system. }\end{array}$ \\
\hline Main competency : \\
a. Prepare a livestock farming business plan, starting from land requirement, maintenance of facilities, required \\
working capital and investments, marketing, and business plan, and financial balance (cash flow). \\
b. $\quad \begin{array}{l}\text { Build farm or livestock businesses ranging from land preparation, facilities, breed, feed, medicines, and other } \\
\text { necessities. }\end{array}$ \\
c. Organize employees in daily livestock maintenance, ranging from the cage, feed and feeding, treatment and \\
prevention of diseases, waste handling, and products and coproduct marketing. \\
\hline $\begin{array}{l}\text { Supporting competencies: } \\
\text { a. Analyzing market potential both for products and materials needed to improve business competitiveness. } \\
\text { b. Develop strategies related to business development or support the farm business as a core business. }\end{array}$ \\
\hline Additional competence: \\
Leadership, communication, internet, and digital literacy.
\end{tabular}

Table 5. Details of roles and subjects to basic competence of the SPAS

\begin{tabular}{|c|c|c|c|}
\hline No. & Competency & Role details & Course subjects \\
\hline 1. & $\begin{array}{l}\text { Business planning } \\
\text { and development. }\end{array}$ & $\begin{array}{l}\text { a. Farm business establishment, ranging from } \\
\text { establishing livestock, land and capital needs, } \\
\text { procurement of materials, marketing, and }\end{array}$ & $\begin{array}{l}\text { 1. Livestock Business Plan } \\
\text { Preparation: Poultry, Dairy, Cut, } \\
\text { Pet Animals, Fish, and Shrimp. }\end{array}$ \\
\hline & & $\begin{array}{l}\text { management system. } \\
\text { b. Business development strategy. }\end{array}$ & $\begin{array}{ll}\text { 2. } & \begin{array}{l}\text { Livestock } \\
\text { Development Strategy }\end{array}\end{array}$ \\
\hline
\end{tabular}




\begin{tabular}{|c|c|c|c|}
\hline 2. & $\begin{array}{l}\text { Procurement and } \\
\text { selection of } \\
\text { breeds. }\end{array}$ & $\begin{array}{l}\text { a. Producing quality breeds of various types of } \\
\text { livestock animals, } \\
\text { b. Selecting and maintaining the right breed for } \\
\text { various raising purposes. }\end{array}$ & $\begin{array}{l}\text { 1. Livestock Breeding Business: } \\
\text { Poultry, Dairy, Beef, Small } \\
\text { Ruminant, Pet Animal, Fish, and } \\
\text { Shrimp. } \\
\text { 2. Selection and Raising of } \\
\text { Livestock Breeds. }\end{array}$ \\
\hline 3. & $\begin{array}{l}\text { Construction and } \\
\text { Maintenance of } \\
\text { Animal Pens, } \\
\text { Grazing Land, and } \\
\text { Facilities. }\end{array}$ & $\begin{array}{l}\text { Designing and building enclosures, grazing land, } \\
\text { and facilities for various types of livestock, age, } \\
\text { and breeding purpose meet the requirements of } \\
\text { comfort, safety, and health. }\end{array}$ & $\begin{array}{l}\text { 1. Design and Manufacture Cage } \\
\text { Livestock: Poultry, Dairy, Beef, } \\
\text { Small Ruminant, Pet Animal. } \\
\text { 2. Design and Manufacture of } \\
\text { Animal Equipment } \\
\text { 3. Cage and Animal Facility } \\
\text { Maintenance Techniques. }\end{array}$ \\
\hline 4. & Livestock Raising & $\begin{array}{l}\text { Regular raising and care for different types of } \\
\text { livestock animals at various age and production } \\
\text { goals }\end{array}$ & $\begin{array}{l}\text { Livestock Raising Techniques: } \\
\text { Poultry, Dairy, Beef Cattle, Pet } \\
\text { Animals, Fish, and Shrimp. }\end{array}$ \\
\hline 5. & $\begin{array}{l}\text { Disease Prevention } \\
\text { and Control }\end{array}$ & $\begin{array}{l}\text { Prevention and treatment of various types of } \\
\text { livestock diseases caused by parasites, fungi, } \\
\text { bacteria, viruses, physical, and other metabolism } \\
\text { disorders. } \\
\text { a. Develop feed formula, feed ingredients, feed } \\
\text { preparation for various types of livestock } \\
\text { animals following the standard requirement of } \\
\text { livestock animals at multiple ages, and } \\
\text { production goals. } \\
\text { b. Feed quality control, analysis methods, and } \\
\text { factors affect the quality of feed raw materials } \\
\text { and ration. }\end{array}$ & $\begin{array}{l}\text { Disease Prevention and Treatment } \\
\text { of Livestock: Poultry, Dairy, Beef } \\
\text { Cattle, Pet, Animals, Fish, and } \\
\text { Shrimp. } \\
\text { 1. Feed Science } \\
\text { 2. Feed and Feeding of Livestock: } \\
\text { Poultry, Dairy, Beef Cattle, Small } \\
\text { Ruminant, Pet Animals, Fish, and } \\
\text { Shrimp. } \\
\text { 3. Feed Manufacturing and } \\
\text { Technology. }\end{array}$ \\
\hline 7. & $\begin{array}{l}\text { Handling and } \\
\text { processing of } \\
\text { Livestock } \\
\text { Products. }\end{array}$ & $\begin{array}{l}\text { a. Capable of handling to maintain the quality of } \\
\text { livestock products immediately after being } \\
\text { produced to be sold or processed, } \\
\text { b. Capable of performing processing in a } \\
\text { practical and straightforward product to } \\
\text { increase the added value of livestock products. }\end{array}$ & $\begin{array}{l}\text { 1. Handling and Processing } \\
\text { Techniques for Animal Products: } \\
\text { Poultry, Dairy, Beef Cattle, Small } \\
\text { Ruminant, Fish, and Shrimp. } \\
\text { 2. Handling and Utilization } \\
\text { Techniques: Skin, Fur, Feces, } \\
\text { Slaughterhouse Byproducts. } \\
\end{array}$ \\
\hline 8. & $\begin{array}{l}\text { Production } \\
\text { Economics and } \\
\text { Marketing } \\
\text { Strategy }\end{array}$ & $\begin{array}{l}\text { a. Capable of applying economic principles in a } \\
\text { farm business. } \\
\text { b. Mastering the marketing strategy both for live } \\
\text { animals and their products } \\
\text { c. Mastering the livestock trading system and } \\
\text { product lines }\end{array}$ & $\begin{array}{l}\text { 1. Production Economics } \\
\text { 2. Livestock Products Marketing: } \\
\text { Poultry, Dairy, Beef Cattle, Small } \\
\text { Ruminant, Pet Animal, Fish, and } \\
\text { Shrimp. } \\
\text { 3. Livestock Trading System: } \\
\text { Poultry, Dairy, Beef Cattle, Small } \\
\text { Ruminant, Pet Animal, Fish, and } \\
\text { Shrimp. }\end{array}$ \\
\hline
\end{tabular}


Table 6. Job opportunities, graduate roles, and competencies, and subject areas of expertise

\begin{tabular}{|c|c|c|c|c|}
\hline Field of Expertise & Job opportunities & Job position & Main competency & Mandatory courses \\
\hline $\begin{array}{l}\text { Animal Nutrition } \\
\text { and Feed } \\
\text { Technology }\end{array}$ & $\begin{array}{ll}\text { 1. } & \text { Feed mill } \\
\text { 2. } & \text { Ranch } \\
\text { 3. } & \text { Breeding farm } \\
\text { 4. } & \text { Poultry shop } \\
\text { 5. } & \text { Feedlot } \\
\text { 6. } & \text { Feed supplier }\end{array}$ & $\begin{array}{l}\text { 1. Feed mill } \\
\text { manager or } \\
\text { supervisor } \\
\text { 2. Nutritionist } \\
\text { 3. Technical service } \\
\text { 4. Feedlot manager } \\
\text { 5. Rancher } \\
\text { 6. Sales } \\
\text { representative } \\
\text { 7. Laboratory } \\
\text { technical support }\end{array}$ & $\begin{array}{l}\text { 1. Implement and develop techniques and } \\
\text { management of livestock farming (including } \\
\text { fish, shrimp, animals, and domestic animals) to } \\
\text { be able to optimize the use of potential natural } \\
\text { resources as feed ingredients } \\
\text { 2. Increase the value for the feed (from the aspect } \\
\text { of nutrition, economic and food security) } \\
\text { through processing technology, handling, } \\
\text { preservation, and storage, } \\
\text { 3. Implement and develop management } \\
\text { techniques and quality control of the feed. }\end{array}$ & $\begin{array}{l}\text { 1. Management of Feed Technology and Industry } \\
\text { 2. Feed Resources Management } \\
\text { 3. Ranch Management } \\
\text { 4. Applied Animal Nutrition } \\
\text { 5. Forage Seed Production } \\
\text { 6. Field and industrial internships } \\
\text { 7. Final scientific work }\end{array}$ \\
\hline $\begin{array}{l}\text { Animal Production } \\
\text { Technology }\end{array}$ & $\begin{array}{l}\text { 1. Livestock production } \\
\text { enterprises } \\
\text { 2. Breeding Farm } \\
\text { 3. Pet shop } \\
\text { 4. Ranch } \\
\text { 5. Feedlot } \\
\text { 6. Livestock supplier } \\
\text { 7. Animal laboratory }\end{array}$ & $\begin{array}{l}\text { 1. Farm manager or } \\
\text { supervisor } \\
\text { 2. Hatchery and } \\
\text { breeder manager } \\
\text { 3. Feedlot manager } \\
\text { 4. Rancher } \\
\text { 5. Inseminator } \\
\text { 6. Technical service } \\
\text { 7. Lab technical } \\
\text { support }\end{array}$ & $\begin{array}{l}\text { 1. Applying and developing the breeding and } \\
\text { management techniques to improve livestock } \\
\text { productivity, product quality, health, } \\
\text { environment, and animal welfare, } \\
\text { 2. Implement and develop techniques to acquire } \\
\text { and produce quality breeds for various } \\
\text { production purposes. } \\
\text { 3. Implement and develop engineering design and } \\
\text { production of livestock equipment and } \\
\text { facilities. }\end{array}$ & $\begin{array}{l}\text { 1. Production of Superior Animal Breeds } \\
\text { 2. Management of Animal Reproduction } \\
\text { 3. Feedlot Technology } \\
\text { 4. Animal Behavior and Welfare } \\
\text { 5. Management of Livestock Breed } \\
\text { 6. Livestock Equipment Production } \\
\text { 7. Biosecurity and Zoonotic Diseases } \\
\text { 8. Field and industrial internships } \\
\text { 9. Final scientific work }\end{array}$ \\
\hline $\begin{array}{l}\text { Livestock Product } \\
\text { Processing } \\
\text { Technology }\end{array}$ & $\begin{array}{l}\text { 1. Dairy processing plant } \\
\text { 2. Slaughterhouse } \\
\text { 3. Meat processing plant } \\
\text { 4. Egg processing plant } \\
\text { 5. Pharmaceutical } \\
\text { companies } \\
\text { 6. Food processing } \\
\text { companies }\end{array}$ & $\begin{array}{l}\text { 1. Plant manager or } \\
\text { supervisor } \\
\text { 2. Laborer } \\
\text { 3. Technical service } \\
\text { 4. Sale } \\
\text { representatives }\end{array}$ & $\begin{array}{l}\text { 1. Implement and develop management and } \\
\text { breeding techniques to improve the quality of } \\
\text { livestock products, } \\
\text { 2. Implement and build methods and management } \\
\text { to increase livestock products' added value as } \\
\text { food, clothing, and raw materials for various } \\
\text { industries (pharmaceuticals, textiles, and } \\
\text { others). }\end{array}$ & $\begin{array}{l}\text { 1. Food Technology and Industry Management } \\
\text { 2. Animal Waste Utilization Techniques } \\
\text { 3. Non-Food Product Production Techniques } \\
\text { 4. Landscape } \\
\text { 5. Field and industrial internship } \\
\text { 6. Final scientific work. }\end{array}$ \\
\hline $\begin{array}{l}\text { The Livestock } \\
\text { Business and } \\
\text { Development }\end{array}$ & $\begin{array}{l}\text { Livestock trading } \\
\text { company } \\
\text { Livestock publications } \\
\text { Financial institution (Bank } \\
\text { and Lending Agencies) }\end{array}$ & $\begin{array}{l}\text { 1. Market analyst } \\
\text { 2. Marketing } \\
\text { manager } \\
\text { 3. Technical service } \\
\text { 4. Sales } \\
\text { 5. Credit analyst } \\
\text { 6. Editor, reporter } \\
\text { 7. Journalist } \\
\text { 8. Privat consulting }\end{array}$ & $\begin{array}{l}\text { 1. Apply economics and social science related to } \\
\text { animal husbandry, } \\
\text { 2. Implement and develop techniques and } \\
\text { management of livestock farming. } \\
\text { 3. Implement and develop the potential of the } \\
\text { various aspects related to livestock as resource } \\
\text { economics and business. }\end{array}$ & $\begin{array}{l}\text { 1. Bank and Credit } \\
\text { 2. Editing and Management of Animal Science } \\
\text { Media } \\
\text { 3. Livestock Business Financing and Investment } \\
\text { Management } \\
\text { 4. Multi-Media } \\
\text { 5. Field and industrial internships } \\
\text { 6. Final scientific work }\end{array}$ \\
\hline
\end{tabular}




\subsection{Learning Process and Learning Outcomes Evaluation}

The curriculum is structured as a guideline for implementing teaching and learning activities by regulating the interaction of student, lecturer, supporting facilities [2]. The learning process could be implemented in various forms, namely lectures, tutorials, seminars, practical laboratory, practical studios, practical workshop, practical field work, research, and community services [7]. The courses need to support by full assignments and practical classes to focus and optimally use the students' time both on campus and outside of class hours. Khalil [8] reported regular practical works in the laboratory improved the students' softs skills and marks. If there are 14-16 class sessions in a semester, then simultaneously, students need at least ten practical sessions in the field or laboratory. Various lecture assignments can be offered in preparation for scientific work, literary translation, data collection, data analysis, class discussion, and presentation [9]. An assignment's report or products should be prepared in various scientific forms, such as model, video, article, graphic info, photos. Intensive assignments will force the students to access information on the current advance in animal science, foreign (English-language) literature, computers, the internet, and other digital devices. Senior students build leadership and other soft skills by involving in research activities and community service (as the object of the practice field or internship) and an assistant in a laboratory and extracurricular activities. A good scheduled classes, practical activities and student assignments can also optimize human resources and facilities. For example, suppose several courses provide theoretical material in the classroom, at the same time, some other subjects hold laboratory experiments and teaching farm, while other topics were discussing in the seminar room. Some other students work in the library or off-campus to complete additional assignments. It will create an optimal scientific climate on campus.

The curriculum is structured as a guideline for implementing teaching and learning activities to achieve intended learning outcomes by regulating students' relationships as students and lecturers as instructors and employees and facilities as supporting facilities [9]. Target achievement of learning outcomes should be evaluated at the end of each year. At the end of the first year, students are expected to master the basic sciences. At the end of year 2, students completed basic competency and able to manage livestock farming. At the end of the 3rd year, students could apply various techniques and skills, and at the end of the 4th year, they have been able to use and develop knowledge and skills in the livestock business. Students are expected to work or have found a job before graduation.

\subsection{Lecturer Career Development}

The person in charge or act as course coordinator should be a Professor, Associate Professor, or senior doctoratedegree lecturer. They are responsible for fostering course subject and junior faculties in the same field science group. Course materials divide into three levels: basic, applied, and advance subjects. Professor and Associate Professor offer primarily the basic and advanced subjects to provide the student insight and motivation through their experiences. The fresh graduate-doctoral lecturer prefers to provide applied material and share their latest knowledge and skills gained during their doctoral education. Master-degree lecturers work more in the laboratory, give tutorials, and help the student to complete their assignments. Their main task is to pursue or complete doctoral studies in the world-class universities outside the Andalas University. Lectures or course instructors should also be involved in the lecturers or faculties from outside the department or faculty to promote positive interactions and communication and to create a scientific climate.

Such regular tasks and roles are expected to form an academic level, mutual care, and sharpening and foster a sense of solidarity. There is a role model in their group field of knowledge. In addition, it is hoped to encourage the faculty members to act outside the campus, both at the university level or a higher institution and in the community. The existence and achievements of the SPAS Campus II Payakumbuh will have positive impacts on the community outside the campus.

\section{CONCLUSION}

It is concluded that the current applied curriculum has not been able to educate students and graduates to master the knowledge, skills, and attitudes of livestock professionals. Curriculum improvement refers to the business or employment opportunities that correspond with areas of expertise. The students and graduates have the competence to form the breeder and manage business related to livestock. The learning process should carry following lecturers' intellectual capacity to ensure student and graduate competencies and career development of lecturers.

\section{ACKNOWLEDGMENTS}

This research was funded by the DIPA-BOPTN of Andalas University 2020, No: SP DIPA023.17.2.677513/2020, 27 December 2019 through Lembaga Pengembangan Pendidikan dan Penjaminan Mutu (LP3M) with contract number: T.026/UN.16.18/PT.01.03/2020. 


\section{REFERENCES}

[1] Kementrian Menteri Riset, Teknologi, dan Pendidikan Tinggi Republik Indonesia, Standar Nasional Pendidikan Tinggi. Peraturan Mentri Nomor 44 Tahun 2015.

[2] Direktorat Jenderal Pembelajaran dan Kemahasiswaan (Belmawa), Panduan Penyusunan Kurikulum Pendidikan Tinggi di Era Industri 4.0. Kementrian Riser dan Pendidikan Tinggi, 2018.

[3] Kementrian Riset, Teknologi, dan Pendidikan Tinggi Republik Indonesia. Peraturan Mentri Nomor 045/U/2002. Tentang Kurikulum Inti Pendidikan Tinggi. Mentri Pendidikan Nasional, 2002.

[4].Panduan Akademik Fakultas Peternakan Universitas Andalas, 2019. http://repo.unand.ac.id/28968/1/Panduan\%20Akadem ik\%202016.pdf.

[5] Khalil, 2015. Penerapan model Experiental Learning dalam kurikulum Pendidikan Ilmu Peternakan. Prosiding Seminar Nasional Pendidikan Tinggi, LP3M Unand, 6-7 Agustus 2015. Padang.

[6] J. R. Gillespie and F. B. Flanders, Modern Livestock, and Poultry Production. Eighth Edition. Delmar, 2010.

[7] L.Anderson, D. Krathwohl, A Taxonomy for Learning, Teaching, and Assessing: A Revision of Bloom's Taxonomy of Educational Objectives. New York: Longman, 2001.

[8] Khalil, Penerapan model Experiental Learning pada mata kuliah PTK 027. Pengawasan Mutu Pakan. Prosiding Seminar Nasional Pengembangan Pendidikan Tinggi Ke III, LP3M Unand, 26 Oktober 2017. Padang. Hal: 191-206, 2017.

[9] J. Rayfield, An Assessment of Recruitment and Training Practices of the National FFA Livestock Career Development Event. Ph.D. Dissertation. The Graduate Faculty of Texas Tech University, 2006. 